\title{
PHOSPHORUS REMOVAL WITH GRASS IN AN APPLE ORCHARD UNDER INFLUENCE OF MULCH AND IRRIGATION
}

\author{
Valentīna Surikova ${ }^{1}$, Aldis Kārkliņšs \\ 1- Latvian State Institute of Fruit growing \\ Graudu iela 1, Dobele, LV 3701 \\ E-mail: valentina.surikova@lvai.lv \\ 2- Latvia University of Agriculture, Institute of Soil and Plant Sciences \\ Lielā iela 2, Jelgava, LV 3001 \\ E-mail: aldis.karklins@1lu.lv
}

\begin{abstract}
Phosphorus leaching from intensive agriculture systems is one of major contributors responsible for pollution of ground-water and surface water bodies. The aim of this study was to determine the content of phosphorus in orchard lawn for reduction of phosphorus fertilizer application and to include the phosphorus from mown grass into P balance and turnover calculation. The investigation was done at the Latvia State Institute of Fruit-Growing in 2009. Three treatments were compared: control, mulch and fertigation. Inter-row strips were covered by grass vegetation. Grass samples were collected at the time of grass mowing. The removal of phosphorus was calculated as kilograms per hectare area. The concentration of phosphorus in the lawn and the height of grass growth were significantly influenced by the mowing time and the soil moisture treatment. These results can be a base for further studies of phosphorus turnover in an orchard, as well as for fertilizer planning and management.
\end{abstract}

Keywords: Malus domestica Mill., mineral nutrition, nutrient uptake.

\section{Introduction}

Phosphorus requirement of apple-trees is lower compared with field crops [1], but it is essential for the provision and transfer of plant genetic information. Phosphorus takes part in plant metabolism, respiration, photosynthesis, facilitates fertilization of flowers. Lack of phosphorus has negative effect on the growth and development of plant reproductive organs (seeds), as well as vegetative parts - trunk, leaves [2, 3]. Phosphorus is also important to sustain soil fertility. Stable, high quality yield can be obtained only providing plants with all necessary nutrients including phosphorous. The main task of fertilization is to compensate that part of plant nutrients which is necessary for plants to secure high yield of prime quality but which can not be provided by the soil. Fertilizing compensates the loss of nutrients from soil which are removed with the harvested yield, pruned branches, leached out from root zone as well as through other losses. Fruit growers constantly try to increase the quantity and quality of the yield which may lead to surplus addition of phosphorus to soil. Although phosphorus movement in soil is relatively slow [4] yet over fertilization can create environment pollution risk as well as unbalanced supply and chemical fixation of micronutrients.

Lack or surplus accumulation of phosphorus in soil greatly depends on the farming methods and growing technologies. It has been found that at farms where fruit remains are mashed and ploughed in (if possible), the total loss of phosphorus is significantly lower, because phosphorus returns to the circulation [5]. The rapidly increasing price of mineral fertilizers stimulates the producer, without loss of yield and income, to choose more rational growing technologies with a suitable fertilization system. If the mown grass is left in the orchard, not only the nutrients come back to the turnover, but also the content of humus in the soil will increase. Thus the buffer capacity of soil increases which in turn preserves nutrients from leaching, as well as improves soil aeration so influencing positively not only the growth of apple-tree roots, but also microbiological processes in soil, increasing and preserving 
sustainable soil fertility. This has become especially important during the latest years, with serious concern for environment and development of organic and integrated fruit growing where mineral fertilizers are used as little as possible.

To provide the practical information for fertilizer planning it is necessary to clarify quantity of phosphorus found in the mown grass depending on technologies used for water supply mulching of soil around trees or establishment of irrigation systems, which may significantly influence the grass biomass as well as concentration of phosphorus in grass.

\section{Materials and methods}

The investigation was carried at the Latvia State Institute of Fruit-Growing, Dobele, in 2009. A field trial in three replications was set up on the basis of an orchard established in 1997, for cultivar 'Melba' on rootstock B9 (planting pattern $1.5 \times 4 \mathrm{~m}$ ). Three kinds of soil water treatment in tree strips were compared: (1) control - no water regulation; (2) sawdust mulch and (3) fertigation, e.g., drip irrigation with fertilizer additives. In the mulching treatment soil surface was covered with a $10-20 \mathrm{~cm}$ layer of sawdust which was renewed every three years. In the irrigation treatment 'Den' type pipelines with built-in drippers spaced $0.38 \mathrm{~cm}$ apart were used. The irrigation provided effective moistening of a $1 \mathrm{~m}$ wide zone in sandy loam soil, which makes about $25 \%$ of orchard area.

For the lawn sown in the inter-row strips Lolium perenne L. and Poa pratensis L. in proportion 1:3 were used. The tree strip in the control and drip irrigation treatments was $1 \mathrm{~m}$ wide, and during the growth season it was maintained free from grasses. The inter-row strips were $3 \mathrm{~m}$ wide. The grass during the experiment was mown regularly ( 3 - 5 times per season). The apple-trees were trimmed as a slender spindle. The average yield was $20 \mathrm{t} \mathrm{ha}^{-1}$ annually. Soil of the experimental plot was Pisocalcic Cutanic Luvisol (Hypereutric, Hyposkeletic, Clayic) [WRB, 2006], fine sandy loam/loam. Organic matter content in soil was $25 \mathrm{~g} \mathrm{~kg}^{-1}$ (according to Tyurin method, wet combustion), soil reaction was $\mathrm{pH} 6.5$ (in $1 M \mathrm{KCl}$ suspension, potentiometrically). Plant-available $\mathrm{P}_{2} \mathrm{O}_{5}$ was $300 \mathrm{mg} \mathrm{kg}^{-1}$ and $\mathrm{K}_{2} \mathrm{O}-190 \mathrm{mg} \mathrm{kg}^{-1}$, MgO- $162 \mathrm{mg} \mathrm{kg}^{-1}$ (according to Egner - Rheem or DL method). This type is typical automorphic soil with relatively good water storage and water supply capacity.

Grass samples were collected during cutting, 3 times per season of 2009: May 20, June 21 and August 11. From the start of the growth season till May 19 the average air temperature was 13.6 ${ }^{\circ} \mathrm{C}$, precipitation $9.3 \mathrm{~mm}$, till June $21-14.8^{\circ} \mathrm{C}$ and $93 \mathrm{~mm}$, till August $11-18{ }^{\circ} \mathrm{C}$ and 96 $\mathrm{mm}$ correspondingly. Grass samples were collected at distances of $0-15 \mathrm{~cm}, 15-30 \mathrm{~cm}$ and $30-45 \mathrm{~cm}$ from the grass-free tree strip. During each sampling the height of grass growth was measured.

Grass samples were dried, they were dry-matter content in \% (ISO 6496). Chemical analyses of grass samples were carried out determining the phosphorus (colorimetrically) content in the ash extract, evaluate as \% of dry matter (ISO 6491). The removal of nutrients was calculated as kilograms per hectare area $\left(\mathrm{kg} \mathrm{ha}^{-1}\right)$.

The results of the investigation were analyzed using dispersion analysis ANOVA, as well as descriptive statistics (Descriptic statistic). To compare the data from two sample groups the Fisher criterion was used.

\section{Results and discussion}

Soil moisture management positively influenced growth of grass in inter-row strips. The applied moisture treatments and mowing time significantly influenced the height of grass growth $(p<0.05)$ (Fig.1). 


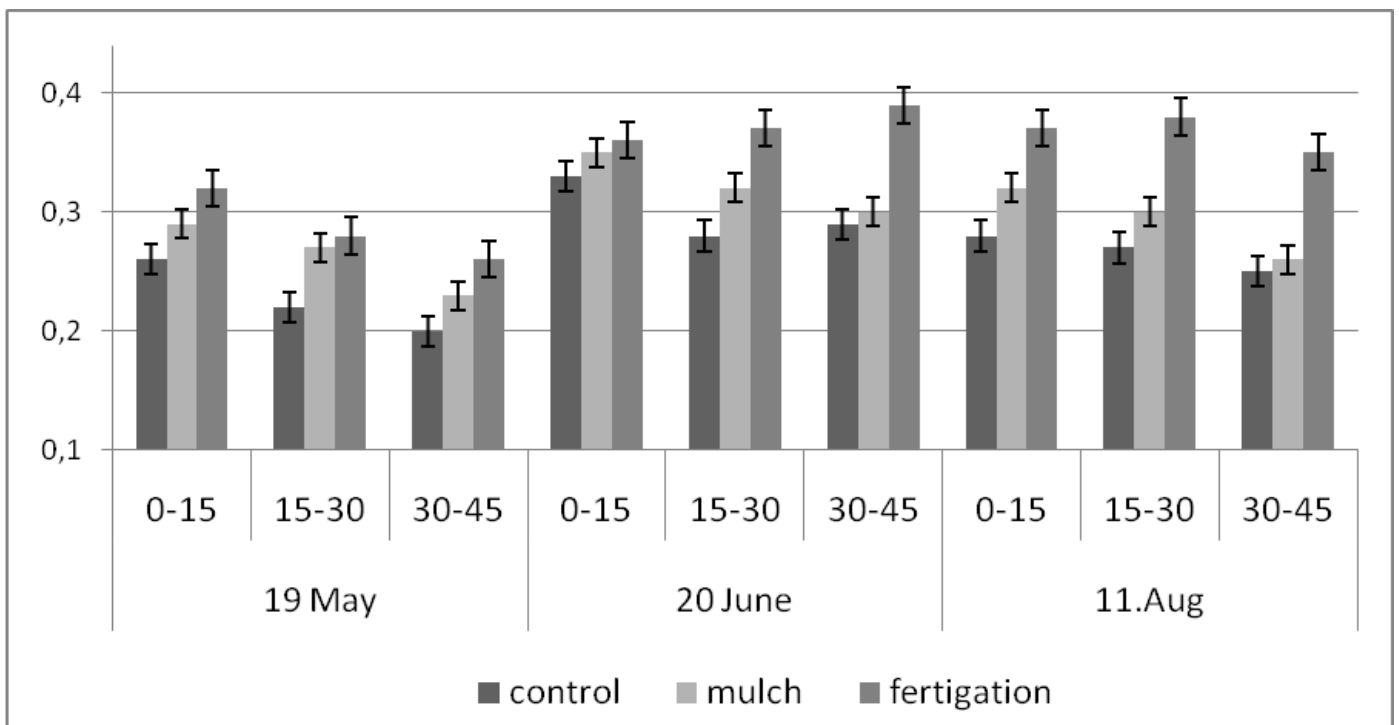

\section{Fig. 1. Height of grass growth at different distances from the tree strip depending of moisture treatment and mowing time, $\mathrm{cm}$}

During the first mowing of grass, the growth at $0-15 \mathrm{~cm}$ distance from the tree strip was higher in the fertigation treatment and the shortest - in the control treatment, this difference was statistically significant. A similar situation was observed also at $30-45 \mathrm{~cm}$ distance from the tree strip. At $15-30 \mathrm{~cm}$ from the tree strip the shortest growth also was in the control treatment, but the growth in mulch and fertigation treatments did not differ significantly. Yet significant influence of fertigation on grass growth in these variants was found during the second and third cutting time. This means that the influence of fertigation may appear later, besides, it must be taken into account that from the beginning of vegetation till the first mowing the precipitation was very low, which can explain the significantly lower grass growth in the control treatment. It is possible that in the control treatment the uptake of nutrients was limited as a result of the drought, as also shown by other investigations [6].

During the second cut, no significant differences between treatments were found at $0-15 \mathrm{~cm}$ from the tree strip. This may be explained by the fact that fertilizer was applied in the tree strips at the beginning of the growing season. By increase of precipitation, the fertilizer uptake by grass near to the tree strip was facilitated in comparison with the first mowing time. At $15-45 \mathrm{~cm}$ from the tree strip significantly higher grass growth was found in the fertigation treatment, while in control and mulch treatments the results showed no significant difference. During the third cut significant differences were found between treatments at $0-15 \mathrm{~cm}$ from the grass-free tree strip. This can be explained by the positive effect of mulch and fertigation on soil moisture, as well as by the relatively high air temperature during this period. Besides, in all treatments a certain tendency was observed - along with increase of distance from the tree strip, the grass growth decreased. These differences may be the result either of the applied soil moisture treatment or the specifics of fertilization in an orchard. Fertilizer was not applied in the whole area, but only in the tree strips, which means that closer to the tree strips the inter-row grass growth could receive more nutrients along with increased uptake due to higher moisture and temperature.

The results of the investigation showed that the concentration of phosphorus in the grass grown in orchard alleyways was influenced by the applied soil moisture regulation treatments - sawdust mulch and fertigation $(n=54, p<0.05)$ (Fig.2). 


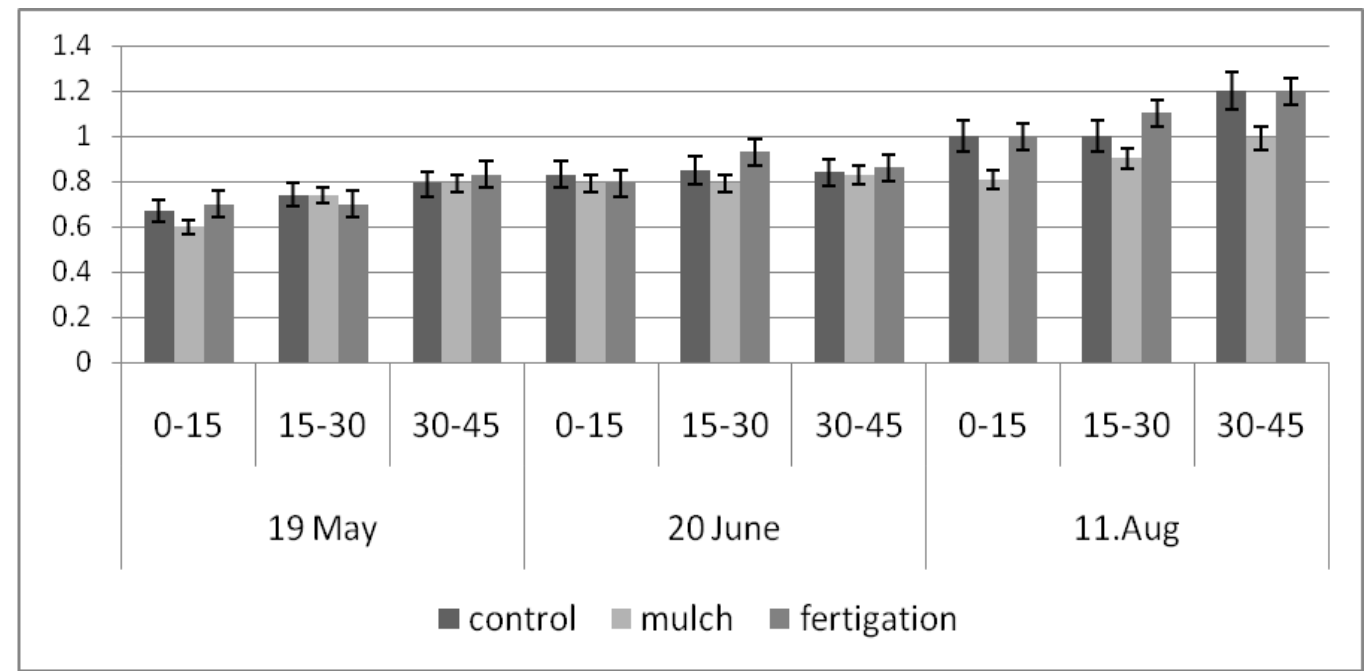

Fig. 2. Content of $\mathbf{P}_{2} \mathrm{O}_{5}$ in grass dry matter at different distances from the tree strip depending on moisture treatment and cut time, $\mathrm{mg} \mathrm{kg}^{-1}$

The concentration of phosphorus in grass was the lowest during the first cut. At $0-15 \mathrm{~cm}$ from the tree strip the lowest phosphorus content was found in the mulch treatment. By increase of the distance from the tree strip, there was a tendency of phosphorus concentration increase in the grass, but significant difference was found only between $0-15 \mathrm{~cm}$ and $30-45$ cm zones.

During the second cut, the concentration of phosphorus in grass was higher by $8-12 \%$, yet no significant differences were found between the first and third mowing times $(p>0.05)$. The relative increase of phosphorus concentration may be explained by changes in precipitation and temperature during this period. The average air temperature increased for $1.2^{\circ} \mathrm{C}$. Changes in phosphorus concentration did not correlate with changes of precipitation, the latest increased even 10-fold during this period. Insignificant changes may be explained by the relatively slow movement of phosphorus in soil and plants [7, 1], which is witnessed by the content of phosphorus during the third grass cut.

During the third cut the content of phosphorus in grass was by $10 \%$ higher than during the first cut and $20 \%$ higher than during the second cut. The differences were significant $(p<0.05)$. During the third cut the phosphorus content in grass had a tendency to increase along with the distance from the tree strip. In the mulch treatment the content also increased this way, but it was lower at all distances from the tree strip in comparison with the control and fertigation treatments. It is possible that mulching of the tree strips with sawdust increased soluble aluminium compound content in soil (as this treatment had lower soil $\mathrm{pH}$ ), while at the same time forming of non-soluble phosphorus compounds increased which are difficult for plant uptake [7, 1]. The results comply with former investigations which founded that for the formation of one ton of grass dry matter about $7.3 \mathrm{~kg}$ of phosphorus is needed [8]. Still it is not possible to ascertain that the concentration of phosphorus in the lawn grass was influenced only by the mowing time. Theoretically the concentration of phosphorus in plants should decrease during the growth season [9], but in this study it was an opposite - the concentration increased. These contradictions may be explained by the fact that the grass was cut down several times during the season and so not allowed to go through all development stages, also it was not in the same stage of development during all mowing times. In the grass mown on May 20 the grasses had already reached beginning of flowering, but on August 11 the mown grass was at a much earlier stage. Yet the development stages of grass were not different among moisture regulation treatments. 
The concentration of phosphorus could be influenced not only by air temperature and precipitation during the growth of grass, but also other factors. Yet at all mowing times there was observed a tendency of mulch reducing the phosphorus concentration in the lawn.

Grass biomass and phosphorus uptake, $\mathrm{kg} \mathrm{ha}^{-1}$

Table 1.

$\mathrm{a}, \mathrm{b}, \mathrm{c}, \mathrm{d}, \mathrm{e}, \mathrm{f},-$ significantly different within columns $(p<0.05)$

$*$ - significantly different within rows $(p<0.05)$

Although the phosphorus concentration in the control and fertigation treatments was significantly higher than in the mulch treatment (Figure 1), still the total removal of phosphorus with mown grass was the lowest in the control treatment, besides, it significantly differed from the $13 \%$ higher phosphorus removal in the fertigation treatment. In the mulch treatment phosphorus removal was $2 \%$ higher than in the control treatment, which was not statistically significant $(p>0.05)$. Such differences were observed because the biomass of the mown grass significantly varied between moisture regulation treatments and mowing times. Till May 20 when the grass was cut for the first time, the precipitation since the start of growth season was only $9.3 \mathrm{~mm}$, therefore in the fertigation and mulch treatments where the soil moisture conditions were presumably better the grass biomass was higher. These results comply with the results of other researchers showing that plant biomass significantly increases when fertigation is used [10].

No similar studies have been done in Latvia, so there are no data about the speed of the decomposition of cut grass and return of phosphorus into the natural turnover, but researchers in other countries $[11,12]$ have found that phosphorus returns into circulation already $1-2$ years after grass mowing. Besides it has been investigated [13, 14] that throwing of cut grass onto the tree strips significantly increases the amount of organic matter in soil, which is favourable for the phosphorus turnover and availability to plants.

It should be added that the results of the study could be influenced by weather conditions and other uncontrollable factors, therefore here are only some tendencies discussed. Yet a similar investigation in Latvian conditions was performed for the first time, and the results may become a base for further studies of phosphorus turnover in an orchard as well as for fertilization planning.

\section{Conclusions}

Mulching of tree strips in an apple orchard significantly reduced the concentration of phosphorus in the mown grass, as well as the height of the cut grass growth.

The phosphorus concentration in grass was significantly influenced by the time of cut during the growth season and the height of grass which in turn was determined by air temperature and precipitation, stage of vegetative development and other factors. 
Annual removal of phosphorus with the biomass of cut grass in the control treatment was 9.98 $\mathrm{kg} \mathrm{ha}^{-1}$, in the mulch treatment it was $2 \%$ higher and in the fertigation treatment $13 \%$ higher $(p<0.05)$.

\section{Acknowledgements}

The investigation was supported by the European Social Fund.

I would like to thank the Vìtolu Fund for granting me a bursary.

\section{References}

1. Neilsen G.H., Neilsen, D., Toivonen P.M. Effective P Fertigation Increases Yield and Quality of Fruit in High Density Apple. Frontiers of Soil Science. Technology and the Information Age. Procceeding of the $18^{\text {th }}$ World Congress of Soil Science, Philadelphia (PA)/USA, 2006, p. 155-132.

2. Nosal K., Poniedzialek W., Kropp K., Porebski S. Effectiveness of Nitrogen and Potassium Fertilization of Apple Trees. Acta Horticulturae, No. 274, 1990, p. 211-214.

3. Fallahi E., Neilsen G. H., Peryea F. J., Neilsen D., Fallahi B. Effect of mineral nutrition on fruit quality and nutritional disirders in apple. Acta Horticulturae, No. 868, 2010, p. 49-59.

4. Raese J. T., Staiff D. C., Visser D. R.. Effect of nitrogen and phosphorus on 'delicious' apple trees grown in caliche soil in the greenhouse. Journal of Plant No. 7, 1984, p. 1433-1442.

5. Līpenīte, I., Kārklinšs, A. Plant Nutrient Balance Studies in Farms of Latvia VI. Farm `Tereni`. Proc. of the Latvia Univ. of Agr. No. 313(18), 2006, p. 9-16 (in Latvian).

6. Nicholas, P. Grape Production. Soil, Irrigation and Nutrition. South Australian Research and Development Institute, Adelaide, No. 2, 2004, p. 201.

7. Haynes J.R., Gog K.M. Distribution and Budget of Nutrients in a Commercial Apple Orchard. Plant and Soil, No.56(3), 1980, p. 445-457.

8. Līpenīte, I., Kārklinšs, A. Calculation of plant nutrient removal for the specification of normatives . Proc. of the Latvia Univ. of Agr. No.4, 2001, p. 35-39 (in Latvian).

9. Nurzinski, J., Kepta, M., Komosa, A., Kozera G. Seasonal changesof N, P, K, Ca and Mg content in apple tree leaves during vegetation period. Acta Horticulturae. No. 274, 1990, p. 365-373.

10. Hornig R., Bünemann G. Fertigation and controlled strip cover by weeds in apple orchrards. Acta Horticulturae, No. 335, 1993, p. 65-72.

11. Shenzuo, F., Huayong, L., Baodong, X. Decomposition and nutrient release of four potential mulching materials for poplar plantations. Agrof. Syst. No. 74, 2008, p. 27-35.

12. Tagliavini, M., Tonon, G., Scandellari, F., Quinones A., Palmieri S., Menarbin G., Gioacchini, P., Masia, A. Nutrient recycling during the decomposition of apple leaves (Malus domestica) and mowed grasses in an orchard. Agr. Ecosyst. \& Environ. No. 118, 2008, p. 191-200.

13. Cazzato, E., Anesse, V., Colreto, A. Effects of clipping management on some aspacts of tall fescue (Fescue arundinacea) turf. Acta Horticulturae. No. 661, 2004, p. 301-307.

14. Eason W.-R, Newman E.-I., Chuba G.-H., Specificity of interplant cycling of nutrients: the role of mycorrhizas. Plant Soil.V.137, 1991, p. 267-274. 